\title{
Reproductive phenology in relation to fire and substrate in coastal Heath near Lancelin, Western Australia
}

\begin{abstract}
Barrett, S. \& Ladd, P. G.: Reproductive phenology in relation to fire and substrate in coastal Heath near Lancelin, Western Australia. — Fl. Medit. 31 (Special Issue): 279-296. 2021. — ISSN: 1120-4052 printed, 2240-4538 online.

Plant reproductive phenology has evolved to enable species to persist within the constraints of the environmental conditions in which they grow. Climate is an important control over phenology but other environmental factors such a disturbance will also influence when reproduction can occur. Quantitative reproductive phenology - flowering and fruiting, were examined in heath (kwongan) and coastal scrub near Lancelin, Western Australia. Two questions were addressed - how is reproductive phenology affected by time since fire and do communities on different substrates under the same climate have different reproductive timing? In five sites with a range of fire histories differences were observed in both within-year reproductive patterns and total reproductive performance. The most prolific flowering occurred early in the season and preceded the time when the majority of species were flowering. Reproductive activity was more seasonally constrained in the most recently burnt site compared with more protracted flowering at the sites several years after fire. Flowering and fruiting were greatest at the longest unburnt site, more than 6 years post-fire. Life history characteristics and juvenile period of species were important influences on reproductive output, with annuals the main contributors to reproduction soon after fire while woody plants took longer to resume or begin reproduction. A comparison of reproductive phenology on a range of substrates showed the coastal dune scrub vegetation to have more protracted reproductive activity than coastal heathland vegetation. Differences of reproductive timing and intensity in heathland vegetation on different substrate types were not marked. Sites on different substrates but with similar fire histories appeared to be more strongly influenced by time since fire than by substrate.
\end{abstract}

Key words: flowering, fruiting, reproductive phenology.

\section{Introduction}

The reproductive phenology of species is one of the key components of community function, being integral to continuation of the species and having ramifications beyond any one particular species if pollinators, seed/fruit dispersers and propagule predators are involved (e.g. Rafferty \& Nabity 2017). Phenology in a general sense is under climatic control. Temperature and water availability are particularly important cues (Segrestin \& al. 2018) while day length 
is also influential for many species at high latitudes and altitudes ( $\mathrm{Li} \&$ al. 2016). In tropical areas seasonality is important and phylogenetic relationships seem to be strongly correlated with time of flowering within seasons (Wright \& Calderon 1995). Within Mediterranean climate regions flowering may also be strongly seasonal but phylogenetic constraints are less apparent (Petanidou \& al. 1995), although in some important South African Cape groups (Restionaceae) evolution of flowering time is related to phylogeny (Linder 2020). While most Mediterranean climate regions are strongly seasonal it is usually water not temperature that is the main environmental factor influencing community function (Dunn \& al. 1976). Overlaid on this climatic skeleton is the influence of frequent fire to which phenological patterns of some species have also developed (Pignatti \& al. 2002; Pyke 2017)

Both the timing and intensity of plant reproduction after fire are significant in terms of fire management and species conservation in heathland ecosystems. Fire may influence plant reproduction in a range of ways eg. fire-stimulated flowering (Gill \& Ingwersen 1976; Gill \& Groves 1981; Lamont \& Downes 2011; Lamont \& al. 2019), more profuse flowering in the early postfire years (Gill \& Groves 1981; Pyke 1983), synchronised flowering and seed production for populations within a species and escape from predation through predator satiation (O'Dowd \& Gill 1984). More successful pollination may also be an outcome as fire has been found to increase pollinator diversity in a number of systems such as central European forests (Bogusch $\&$ al. 2015) and abundance of pollinators in Mediterranean pine forests (Lazerina \& al. 2017). However, a high frequency of fire may be inimical to reproduction due to depleted soil resources (Carbone \& Aguilar 2017). The establishment of seed banks is influenced by juvenile period and the time required to first set seed after fire (Benson 1985; van der Moezel \& al. 1987; Muir 1987; Wills 1989). Species composition may also be affected by time since fire; species richness is often greatest in the early post-fire years (Pate \& al. 1985; Bell \& Koch 1980) particularly in Australian heaths.

Studies of reproductive phenology in heath or shrubland vegetation have focussed mainly on seasonal variation in flowering and have been either descriptive in nature or have detailed only the number of species flowering each month (eg. Specht \& al. 1981; Milewski \& Davidge 1981; Bell \& Stephens 1984). While flowering of certain species is abundant after fire, giving the impression of communities highly attuned to episodic disturbance, it has not been well documented just how important this is in terms of whole community reproductive effort over time. There have been few quantitative studies of reproductive phenology or changes in reproductive intensity in relation to fire on a community basis (e.g. McFarland 1990; Petanidou \& al. 1995).

The effects of substrate on community flowering patterns in heath and shrublands have been investigated by Wills (1989), McFarland (1990) and Pierce \& Cowling (1984). Substrate influences both the nutrient availability and water retention capability of the soil. Substrate has been proposed as a major determinant of phenophases in mediterranean-type ecosystems through an interplay of water availability and nutrient cycling (Specht \& al. 1983). Heathlands in Australia occur on a number of different substrate types. Casual observation suggests that flowering phenology varies in relation to soil type but there have been no detailed studies examining communities on different substrates.

The aims of this study were to quantify flowering and fruiting cycles in coastal heath in south western Australia. Both the timing and intensity of flowering and fruiting were examined in relation to fire and substrate in order to determine the relative influence of these factors on reproductive phenology. 


\section{Methods}

This study was undertaken near Lancelin Western Australia $\left(31^{\circ} 01^{\prime} \mathrm{S}, 115^{\circ} 20^{\prime} \mathrm{E}\right)$. The climate is strongly mediterranean (annual rainfall $627 \mathrm{~mm}$ ) most of which falls in winter. Temperatures range from an average maximum of $30^{\circ} \mathrm{C}$ in summer; $19^{\circ} \mathrm{C}$ in winter and average minimums of $16-18^{\circ} \mathrm{C}$ in summer; $10^{\circ} \mathrm{C}$ in winter (Fig. 1). The study sites were located on two sections of a chronosequence of late quaternary near-coastal sand dunes (Turner \& al. 2018).

Five sites were chosen for sampling in coastal heathland in Nilgen Nature Reserve, $6 \mathrm{~km}$ north east of Lancelin (approximately 30 $57^{\prime} 48.00^{\prime \prime} \mathrm{S} 115^{\circ} 21^{\prime} 05.00 \mathrm{E}$ ). These sites were located on deep acid sands in close proximity to each other and were representative of a range of fire histories. Time since last fire was 1, 2.5, 5, 6 and greater than 6 years corresponding to sites 1 (1990), 2 (1988), 3 (1986), 4 (1985), and 5 (pre-1985). Heath on sandy substrates in this area of Australia is referred to as kwongan - basically sand heath (Beard \& Pate 1984). An additional five sites were located on a range of substrate types, site 6 (long unburnt, $>8$ years) on skeletal soils of a limestone ridge (7 km north east of Lancelin), sites 7 (burnt 1991) and 8 (long unburnt, $>8$ years) on deep calcareous sands and sites 9 and 10 (both long unburnt, $>8$ years) on unconsolidated coastal sand-dunes (about $4 \mathrm{~km}$ south of Lancelin, Table 1). At each site three randomly selected $3 \mathrm{~m} \times 3 \mathrm{~m}$ plots were established. During monthly visits to each site from March 1991 to February 1992 quadrats were investigated for species flowering and fruiting. 'Intensity' was estimated by means of a logarithmic scoring system (McFarland 1990) (1 = one flower or fruit per quadrat, 2 = a few flowers or fruits per quadrat, 3 = flowers or fruits common in quadrat, 4 = profuse flowering or fruiting in quadrat).

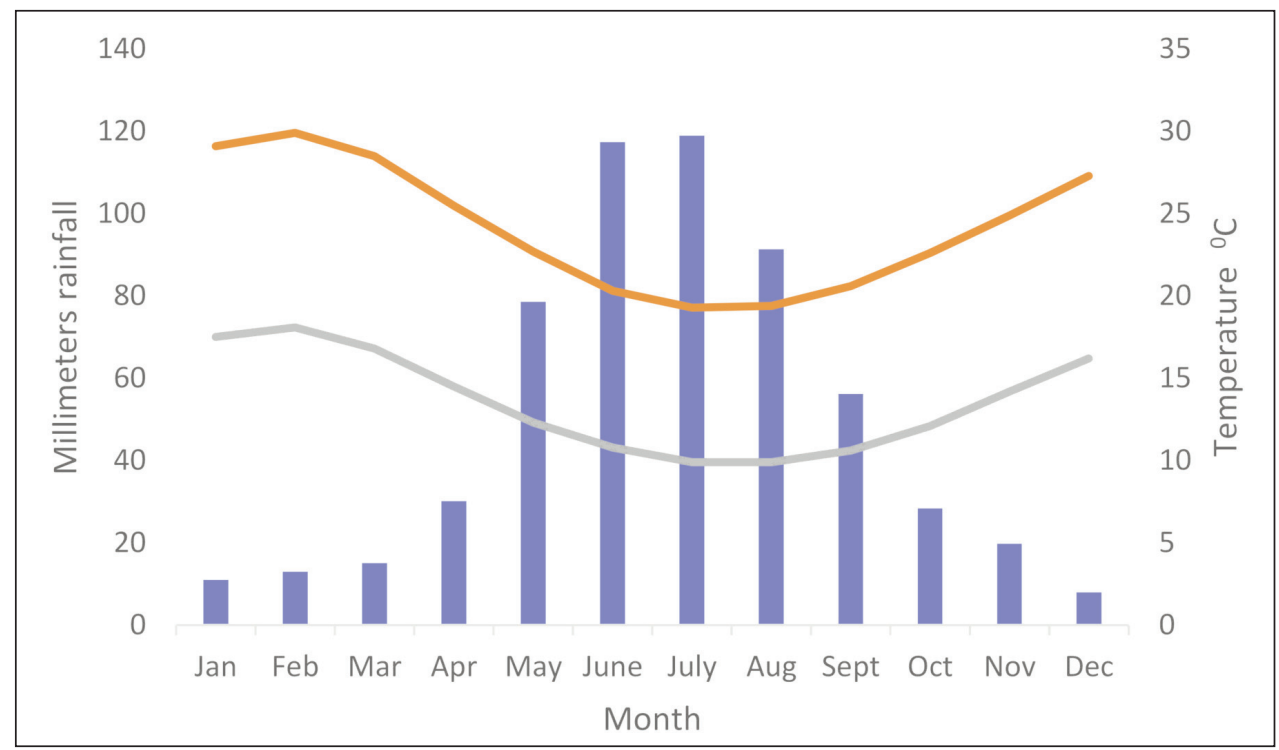

Fig. 1. Annual rainfall and temperature for the Lancelin weather station that is close to the study sites - orange line is maximum mean temperature and the grey line minimum mean temperature. 
Table 1. Site characteristics.

\begin{tabular}{|c|c|c|c|c|c|c|c|c|c|c|}
\hline $\begin{array}{l}\text { Dominant } \\
\text { species }\end{array}$ & $\begin{array}{l}\text { Hibbertia } \\
\text { hypericoides, } \\
\text { Hypocalymma } \\
\text { xanthopetalum }\end{array}$ & $\begin{array}{l}\text { Acacia } \\
\text { lasiocarpa, } \\
\text { Jacksonia } \\
\text { stricta } \\
\end{array}$ & $\begin{array}{l}\text { Jacksonia } \\
\text { stricta, } \\
\text { Hibbertia } \\
\text { hypericoides }\end{array}$ & $\begin{array}{l}\text { Banksia } \\
\text { sessilis, } \\
\text { Hakea } \\
\text { trifurcata }\end{array}$ & $\begin{array}{l}\text { Banksia } \\
\text { leptophylla, } \\
\text { Bankia } \\
\text { sessilis }\end{array}$ & $\begin{array}{l}\text { Banksia } \\
\text { sessilis, } \\
\text { Hibbertia } \\
\text { hypericoides }\end{array}$ & $\begin{array}{l}\text { Melaleuca } \\
\text { systena, } \\
\text { Phyllanthus } \\
\text { calycina } \\
\end{array}$ & $\begin{array}{l}\text { Melaleuca } \\
\text { systena, } \\
\text { Acacia } \\
\text { lasiocarpa }\end{array}$ & $\begin{array}{l}\text { Myoporum } \\
\text { insulare, } \\
\text { Scaevola } \\
\text { crassifolia }\end{array}$ & $\begin{array}{l}\text { Myoporum } \\
\text { insulare. } \\
\text { Olearia } \\
\text { axillaris }\end{array}$ \\
\hline Post-fire age & 1 year & 2.5 years & 5 years & 6 years & $\begin{array}{l}\text { Long } \\
\text { unburnt }\end{array}$ & 5 years & 1 year & 2 years & $\begin{array}{l}\text { Long } \\
\text { unburnt }\end{array}$ & $\begin{array}{l}\text { Long } \\
\text { unburnt }\end{array}$ \\
\hline $\begin{array}{l}\text { Geomorphic } \\
\text { unit }\end{array}$ & \multicolumn{6}{|c|}{ Spearwood } & \multicolumn{4}{|c|}{ Quindalup } \\
\hline $\mathrm{pH}$ & 6.7 & 6.3 & 6.4 & 6.7 & 6.5 & 6.3 & 8.4 & 8.0 & 8.7 & 8.7 \\
\hline
\end{tabular}

Inflorescences or infructescences such as those of Banksia and Stackhousia species were counted as single flowers or fruits. Species noted to be flowering from casual observation within $50 \mathrm{~m}$ of each site were also recorded. However, this excluded individuals flowering near disturbed areas such as trails or firebreaks.

Total annual flowering and fruiting scores for each site were analysed by means of a oneway analysis of variance (SPSS Inc. 1986). The data were analysed in two groups: (i) fire history: sites 1-5; (ii) substrate: sites 5, 6, 8-10.

\section{Results}

Flowering and fruiting data were obtained for 198 species. Data on the intensity of flowering and fruiting were obtained for 162 species which occurred within site quadrats. Sites on the Quindalup sands, particularly sites 9 and 10 on a near-coastal dune were much less species rich than those on the older Spearwood sands (Table 2).

\section{Time Since Fire}

The number of species which did not flower was highest in the more recently burnt sites. Therophytes dominated flowering in the first year with a sudden upsurge of flowering following

Table 2. Lifeform composition of the study sites.

\begin{tabular}{lcccccccccc}
\hline LifeformlSite & 1 & 2 & 3 & 4 & 5 & 6 & 7 & 8 & 9 \\
\hline Therophyte & 23 & 1 & 1 & 4 & 0 & 7 & 19 & 7 & 5 \\
Geophyte & 1 & 4 & 7 & 5 & 1 & 4 & 3 & 3 & 0 & 0 \\
Hemicryptophyte & 4 & 8 & 9 & 7 & 5 & 9 & 3 & 8 & 4 \\
Chamaephyte & 6 & 10 & 5 & 5 & 10 & 5 & 6 & 10 & 1 & 4 \\
Phanerophyte & 4 & 29 & 20 & 23 & 14 & 26 & 0 & 6 & 6 & 4 \\
Other & 0 & 1 & 1 & 2 & 1 & 1 & 0 & 0 & 0 \\
Total no. of species & 39 & 55 & 46 & 50 & 36 & 58 & 38 & 43 & 25 \\
\hline
\end{tabular}


fire but decreased dramatically to a generally constant low level in the following years. In contrast, phanerophyte flowering increased from a very low level at one year post fire to account for almost half the species flowering on the long unburnt site (Fig. 2a). Species richness rose in the initial post-fire period reaching a maximum at 2.5 years post-fire (site 2/1988).

Flowering intensity showed a different pattern from number of species flowering (Fig. 2b). On the long unburnt sites flowering intensity peaked before the majority of species flowered. The most recently burnt site (site 1, 1990) had the lowest while site 5 (pre 1985) had the highest total flowering intensities for the year. On site 5 most species flowered in October (mid spring) but flowering intensity was highest in late winter and early spring (August, September). The site burnt in 1985 (5 years before) had more species flowering in September and October but similarly, greatest intensity in August and September.

The pattern of fruiting intensity and number of species in fruit was more closely similar than was the case for flowering (Fig. 3a, b). In addition, the fruiting pattern generally showed a similar pattern to flowering but occurred a month later. All except the most recently burnt site showed peaks of intensity and number of species fruiting in November; this site showed a peak in October. Fruiting intensity was most evenly spread and was highest in the longest unburnt site 5 .

A one-way analysis of variance failed to show a significant effect $(P>0.05)$ across sites with different fire histories for total annual flowering or fruiting scores in sites 1 - 5 .

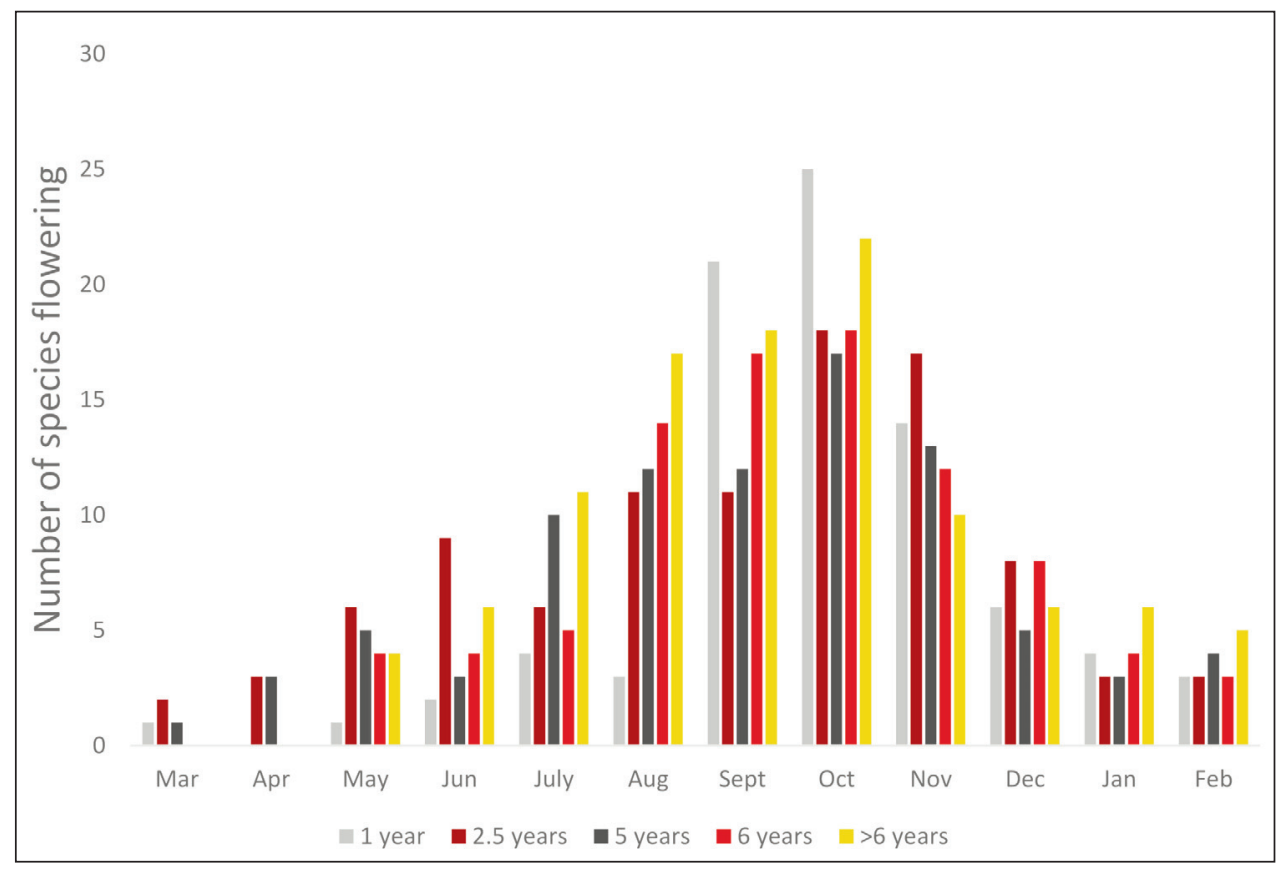

Fig. 2a. Number of species flowering per month at the sites $(1-5)$ used in the "time since fire" study. 


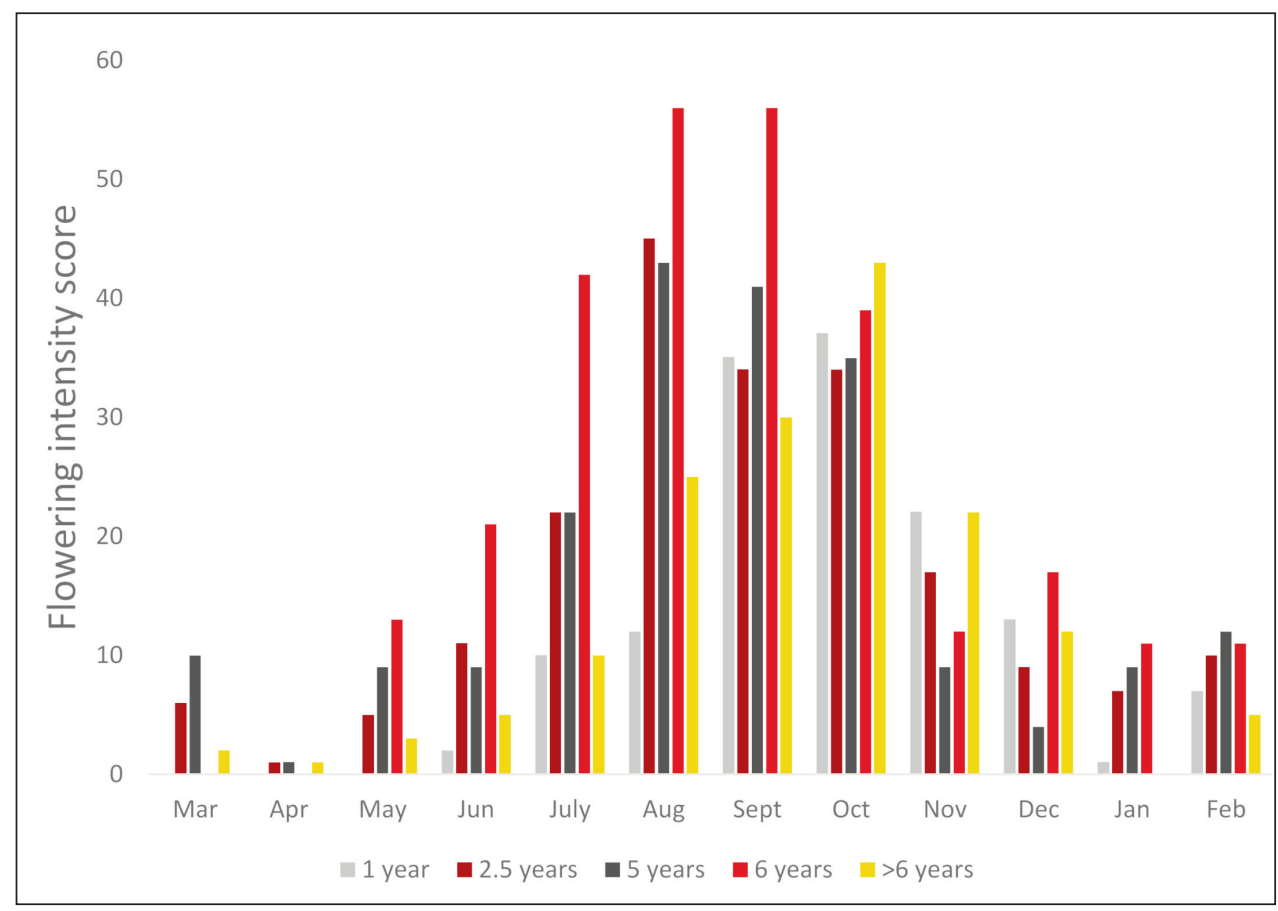

Fig. 2b. Flowering intensity at the sites $(1-5)$ used in the "time since fire" study.

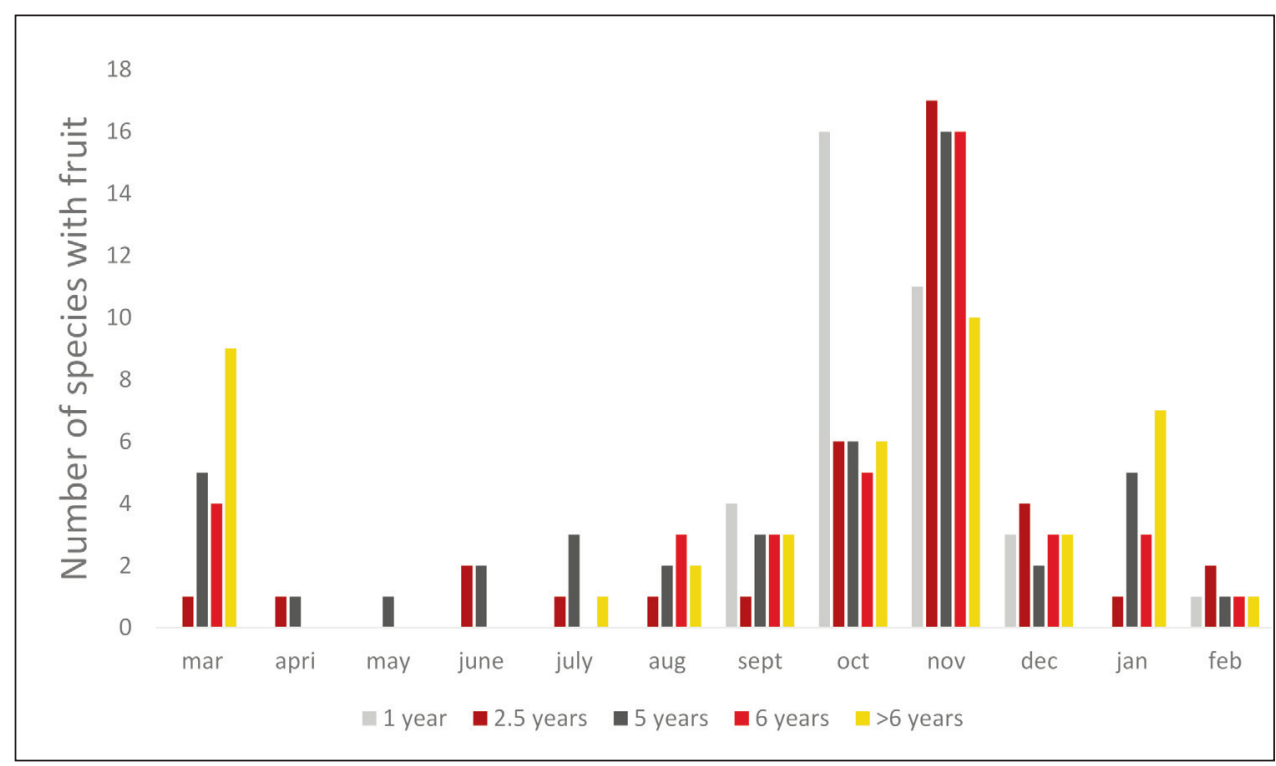

Fig. 3a. Number of species in fruit in each month at the sites (1 - 5) used in the "time since fire" study. 


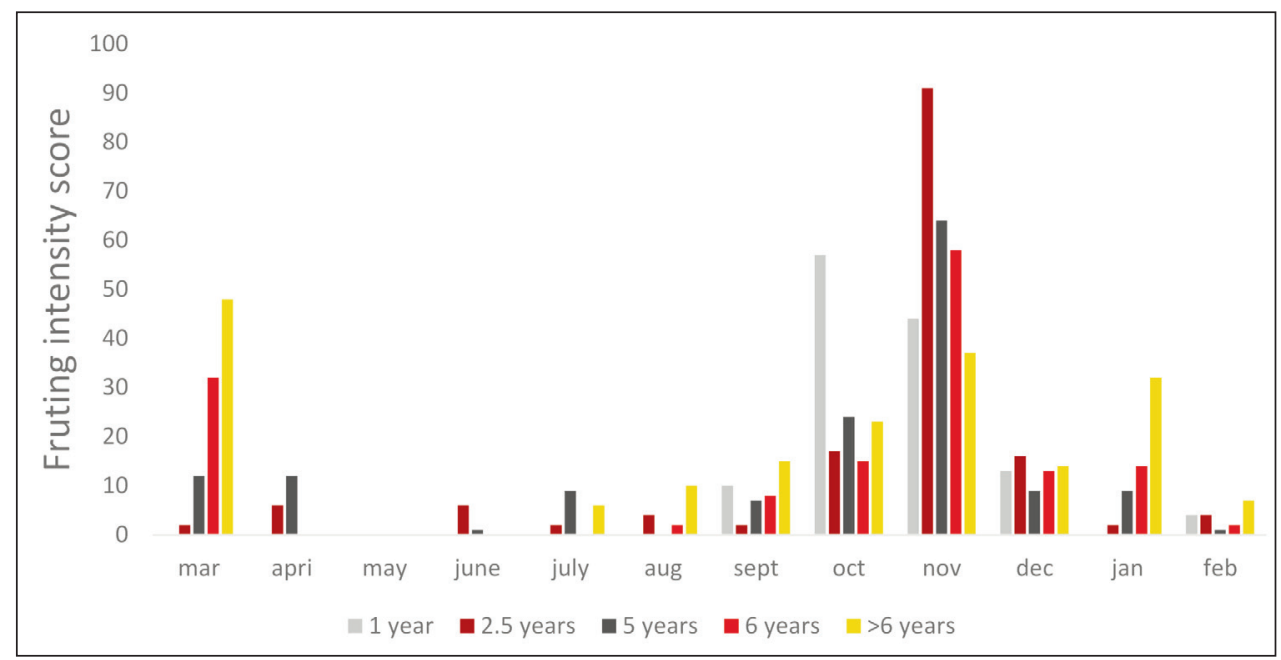

Fig. 3b. Fruiting intensity at the sites $(1-5)$ used in the "time since fire" study.

\section{Substrate}

Species richness in the coastal dune sites was considerably lower than that of the other sites contrasting markedly with the species-rich site 6 on skeletal limestone soil. Thus, there were a smaller number of species that flowered at these dune sites (Table 2). Flowering intensity on the deep sand Spearwood site (Site 5) was much higher and earlier than on the geologically more recent Quindalup sands (Sites 9 and 10). Although the number of species flowering and flowering intensity in the coastal dune sites was low, flowering was relatively high in late winter and into mid spring (Fig. 4a, b). Total annual flowering intensity scores were highest in sites 6 and 8 and lowest in the coastal dune sites.

Total species with fruit was highest in November (Fig. 5a) for the shallow soil limestone site (site 6), a month later than the maximum flowering and for the heath on Quindalup sand (site 8) and the foredune site (site 10). Total fruiting intensity scores followed a similar pattern to that of flowering intensity (Fig. 5b). The foredune sites (sites 9 and 10) had few species fruiting and low intensity due to low species richness and was generally absent or very low in winter compared to the other sites but carried on into the summer and autumn.

Site 5 in the Nature Reserve sites was included with sites 6, 8, 9, 10 in a one way analysis of variance which showed it was statistically valid to test for differences in number of species flowering between sites $(p<0.05)$. However, Tukey's multiple range test showed that the only significant differences were between site 5 in the Nature Reserve and sites 9, 10 (the coastal dune sites). The analysis of variance for number of species fruiting also showed it was statistically valid to test for differences between sites $(p<0.05)$. However multiple range tests showed no two pairs of sites to be significantly different.

Comparing sites on different substrates with similar fire history shows that the flowering and fruiting patterns of site 1 on brown siliceous sands of the Spearwood System and site 7 on calcareous sands of the Quindalup System, both recently burnt, show marked similarities. 
At both sites there was a similar upsurge of flowering in spring driven particularly by the many annuals flowering in the first year after fire (Fig. 6a, b). As with the other sites, number of species fruiting and fruiting intensity peaked a month later (Fig. 7a, b).

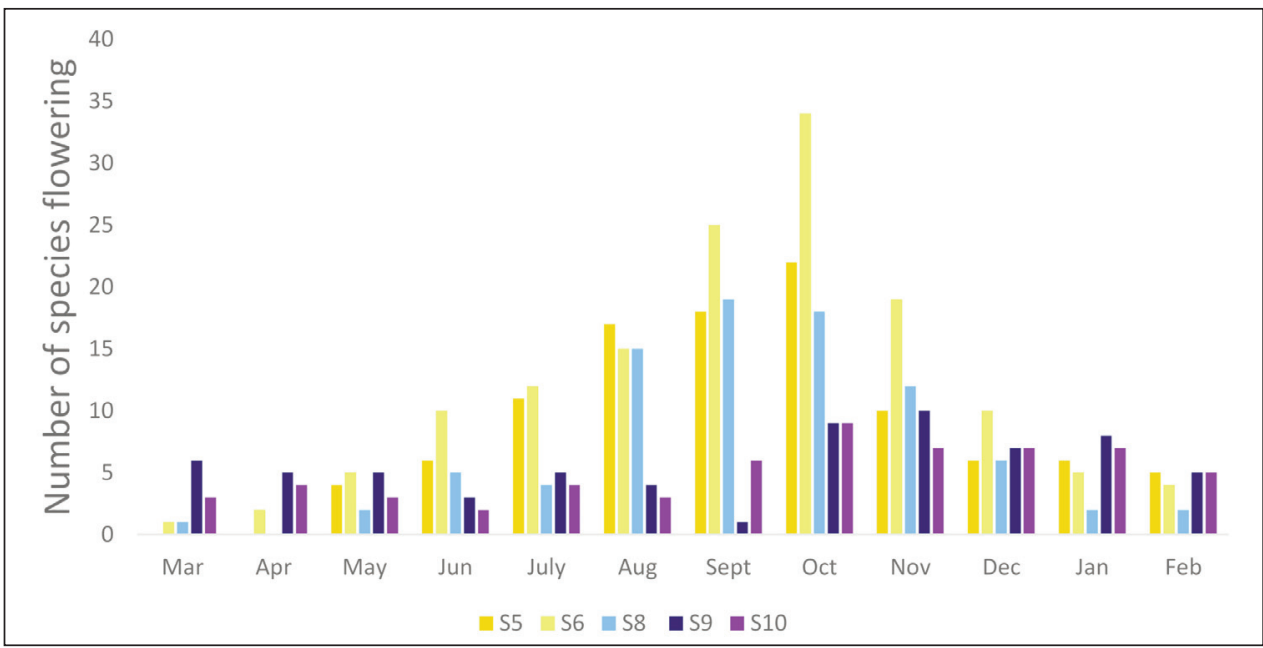

Fig. 4a. Number of species flowering per month at the sites $(5,6,8-10)$ used in the substrate study.

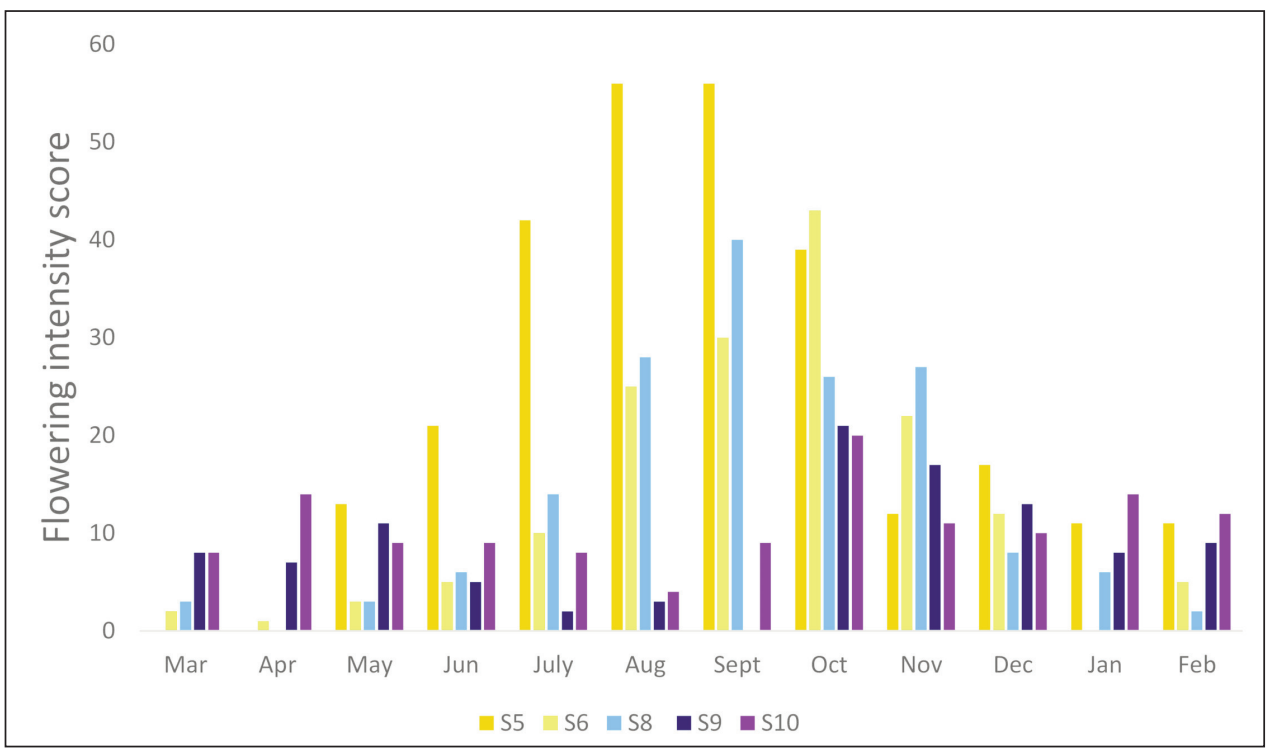

Fig. 4b. Flowering intensity per month at the sites $(5,6,8-10)$ used in the substrate study. 


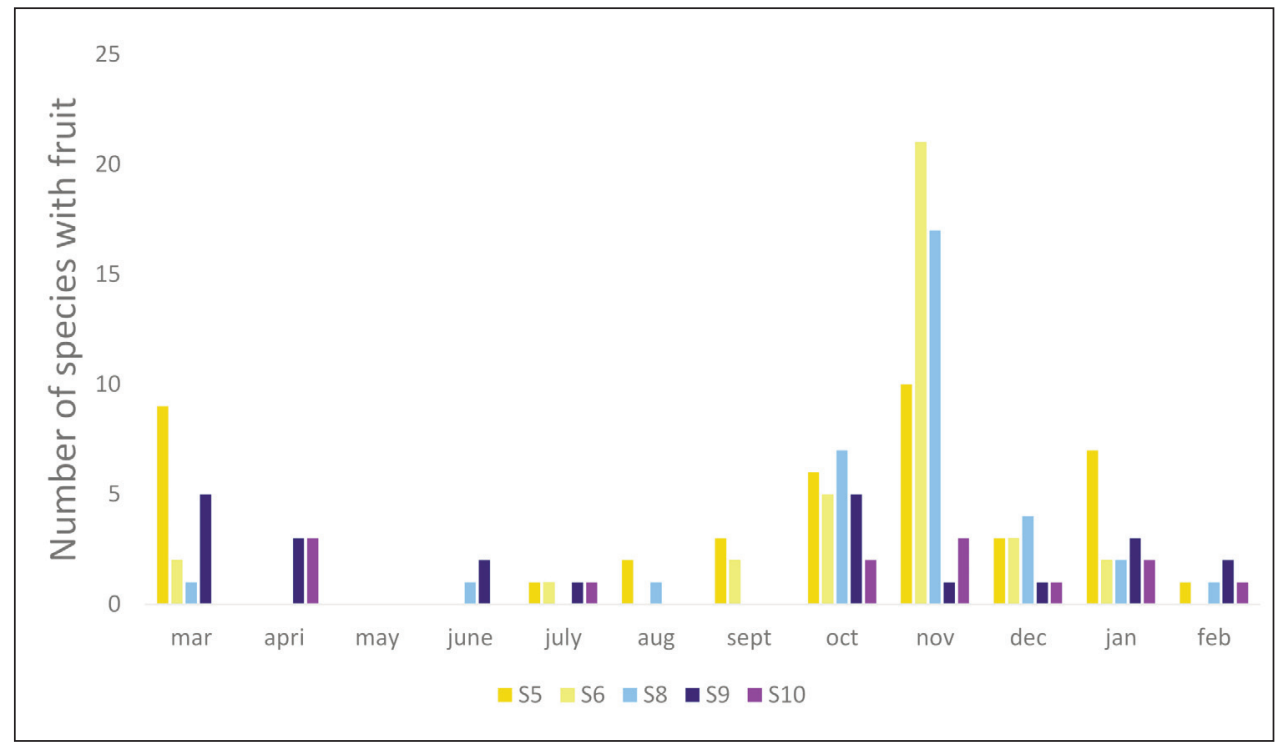

Fig. 5a. Number of species fruiting at the sites $(5,6,8-10)$ used in the substrate study.

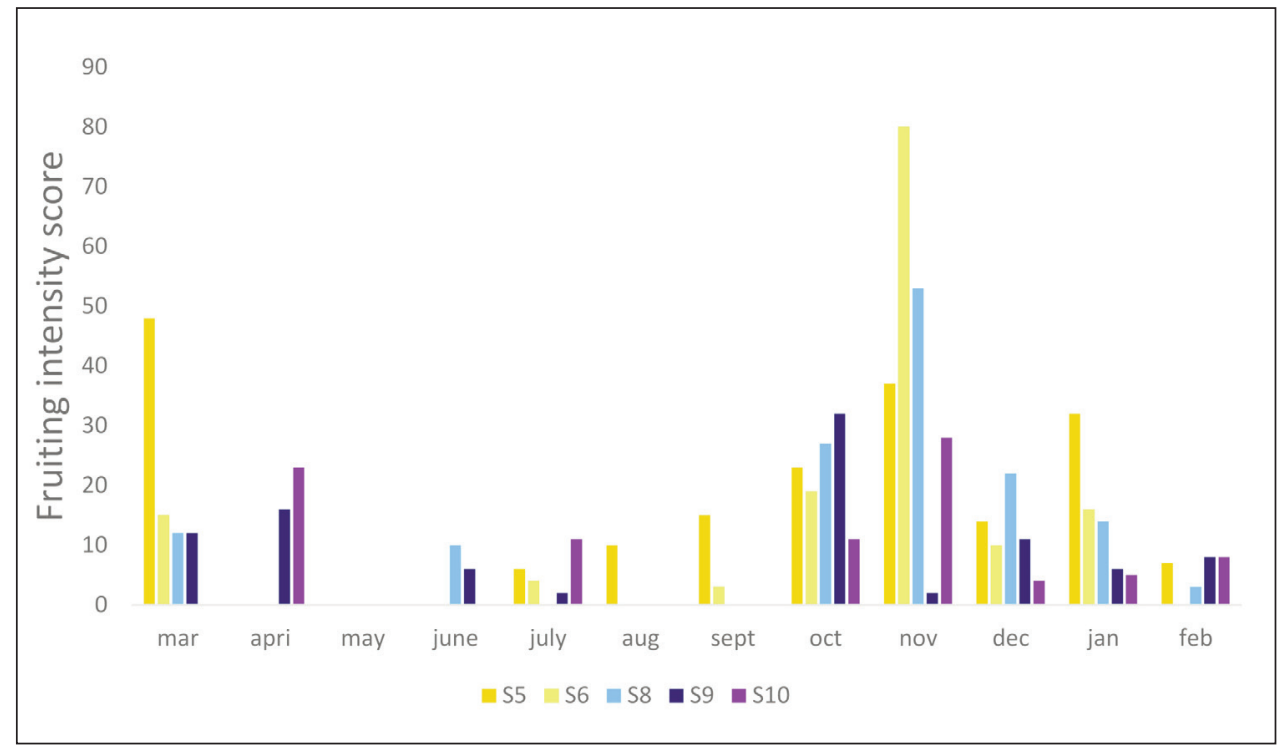

Fig. 5b. Fruiting intensity at the sites $(5,6,8-10)$ used in the substrate study. 


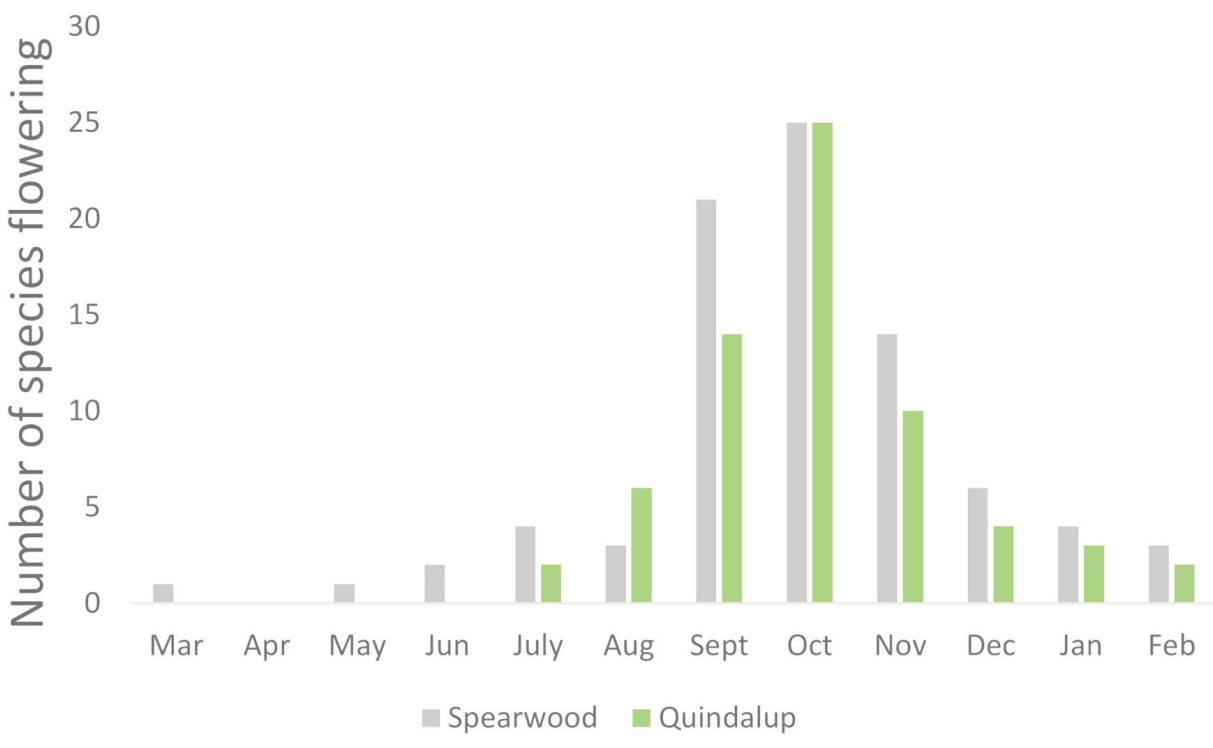

Fig. 6a. Number of species flowering per month at the sites 1 and 7 - both one year after fire.

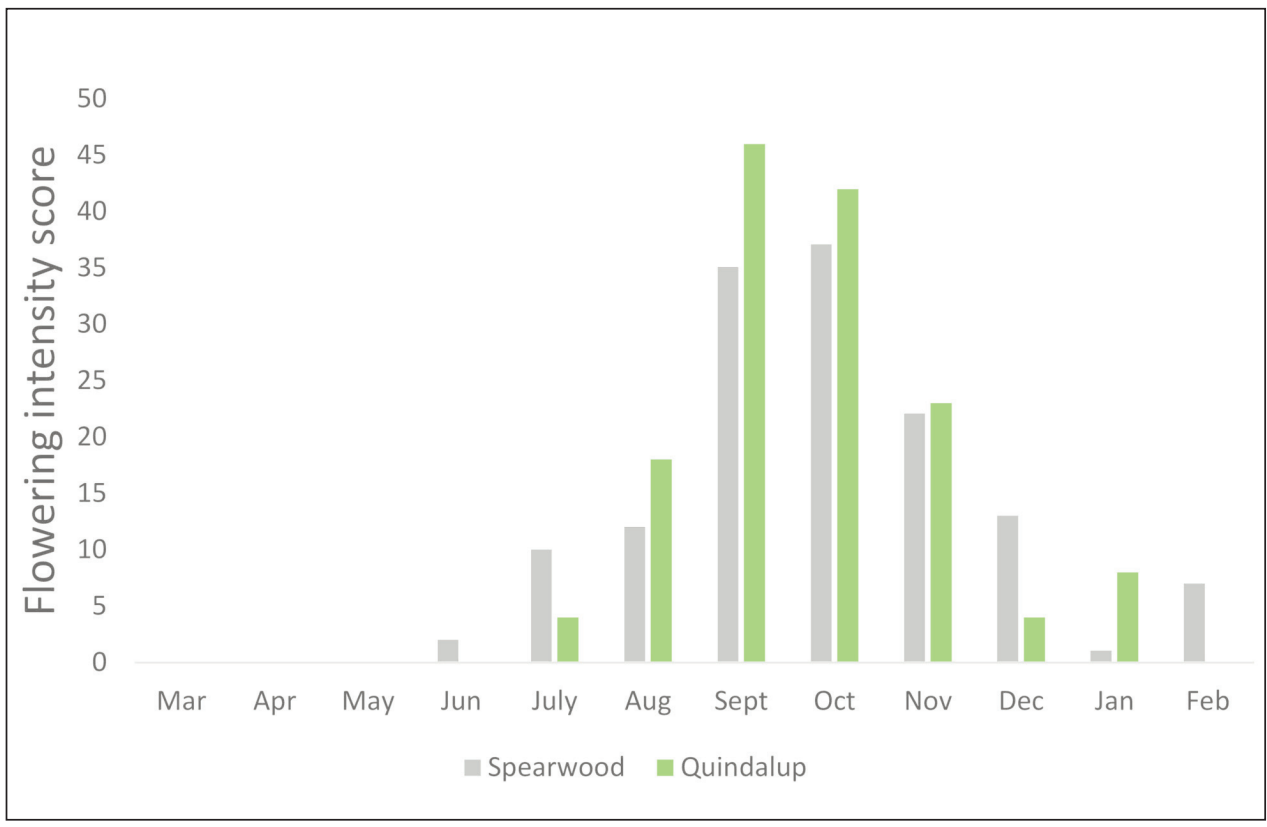

Fig. 6b. Flowering intensity per month at the sites 1 and $7-$ both one year after fire. 


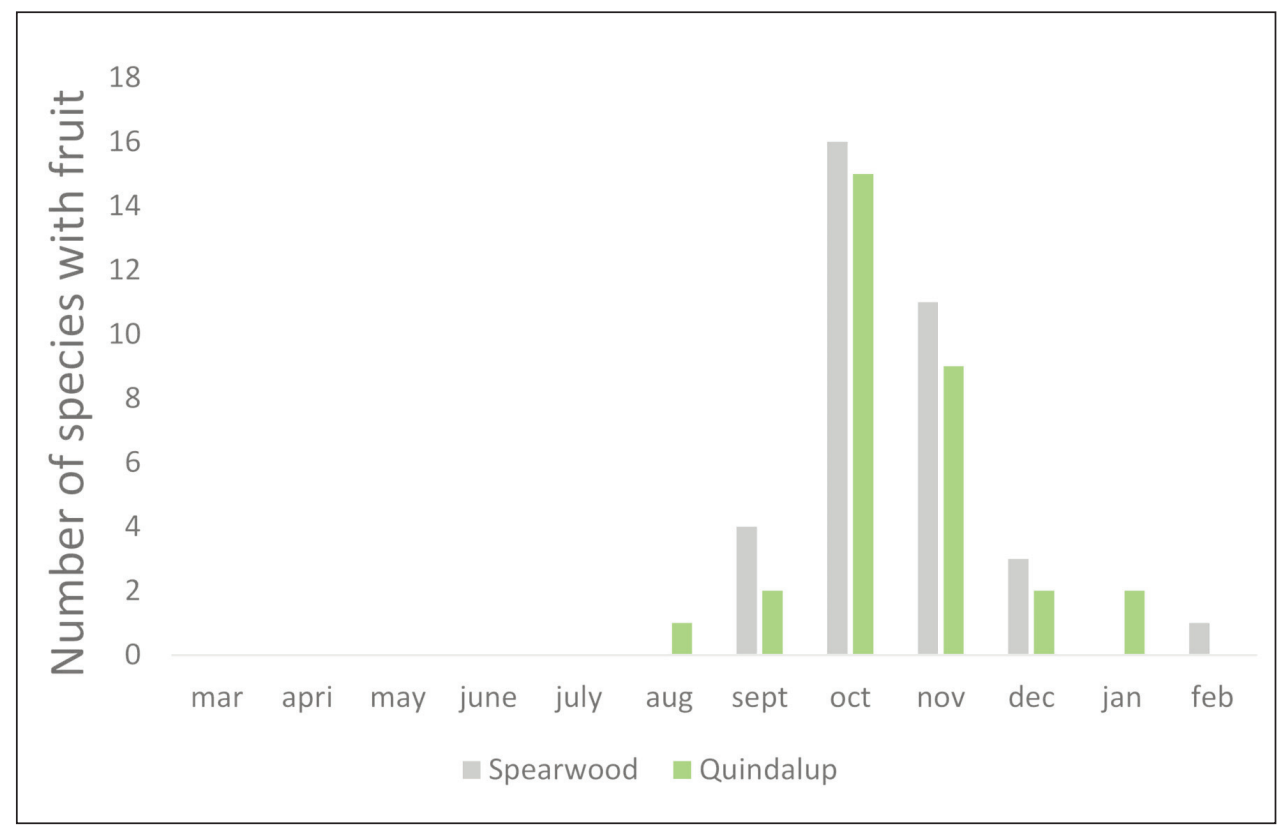

Fig. 7a. Number of species fruiting per month at the sites 1 and 7 - both one year after fire.

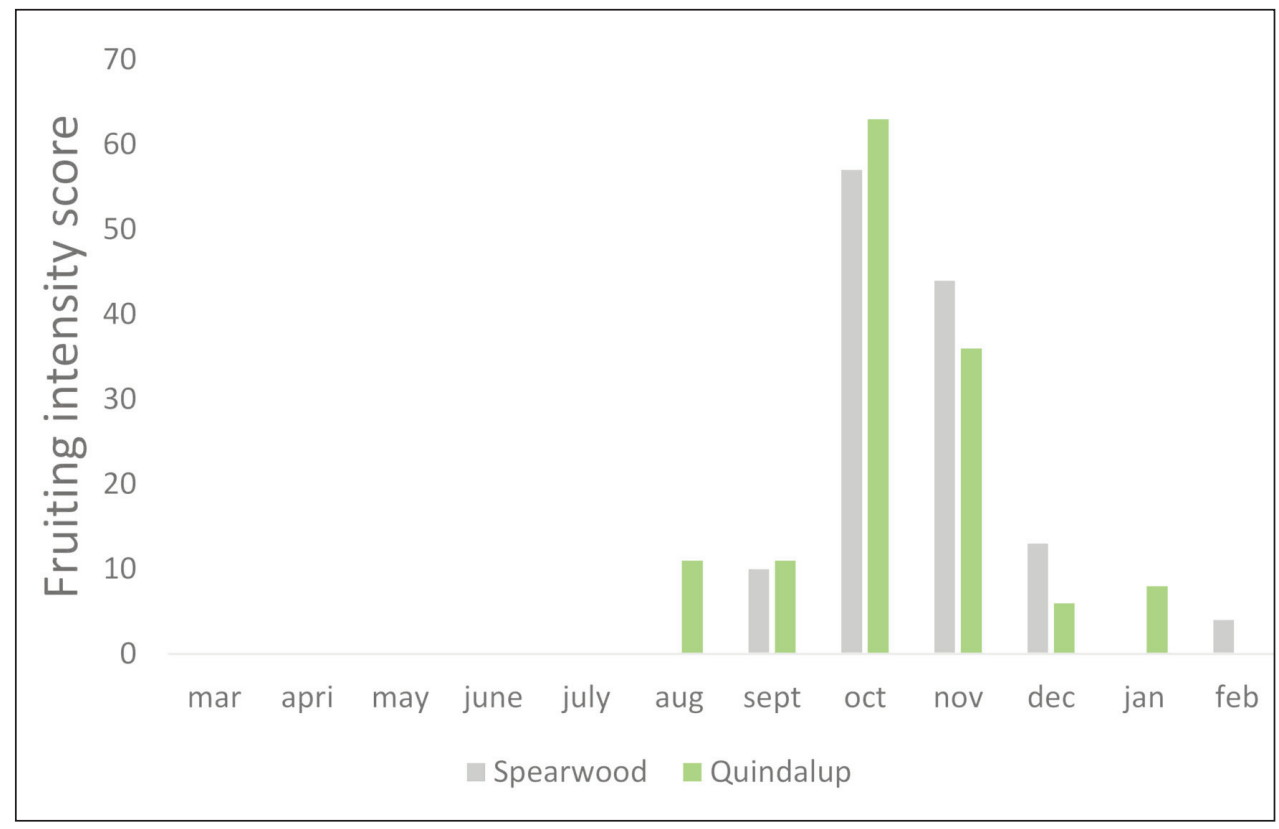

Fig. 7b. Fruiting intensity per month at the sites 1 and 7 - both one year after fire. 


\section{Discussion}

The pattern of a spring peak in flowering seen in the Lancelin heaths is typical of that of other heathlands in Mediterranean-type climates (Bell and Stephens 1984). The timing of the peak, however, shows some variation within Western Australian heaths and shrublands. The greatest number of species flowering in the Lancelin area was in early October. However, the greatest flowering intensity was earlier and in these heathlands species in the Fabaceae, particularly Acacia, are some of the earliest to flower, beginning in mid-winter (pers obs). In the Mt Lesueur area $100 \mathrm{~km}$ to the north the peak was earlier, in August (Wills 1989), at Badgingara $80 \mathrm{~km}$ north-east it was in late September (van der Moezel \& al. 1987) and in the Perth region, $125 \mathrm{~km}$ south, flowering peaked mid-October (Bell \& Stephens 1984; Gentilli 1996). Therefore, the peak number of species flowering is later with distance to the south. Bell and Stephens (1984) related this to interactions of the environmental factors daylength, temperature and soil moisture and Gentilli (1996) demonstrated a very good correlation between flowering and monthly rainfall lagged by 2-3 months plus an influence of low winter temperatures. This correlates with results from the cool temperate climate of Chile under a rainfall regime of $1600 \mathrm{~mm} / \mathrm{a}$ where flowering occurs much later in the year, in late spring extending into summer, and is primarily related to temperature (Smith-Ramirez and Armesto 1994).

The spring onset flowering pattern in the south-western Australian heaths is similar to that seen in southern California, Israel, Chile (Bell and Stephens 1984), Spain (Hererra 1986), Greece (Petanidou \& al. 1995), France (Segrestin \& al. 2018) and to the winter rainfall area of the South African Cape (Johnson 1993). The Lancelin dune community was more similar to the pattern found in the non-seasonal rainfall area of the eastern Cape (Johnson 1993) with flowering extending more into the summer.

In contrast the single peak in flowering in heathlands in the south western Australian Mediterranean climate does not match with the bimodal flowering and fruiting activity in subtropical heaths in Queensland (Specht \& al. 1981; McFarland 1990) and lacks the late spring and summer secondary peak of mostly woody species in France (Segrestin \& al. 2018) or any autumn subsidiary peak of flowering as recorded for phrygana in Greece (Petanidou \& al. 1995).

\section{Time Since Fire}

The visual impression of abundant flowering in the early years post-fire (Specht 1981) which can be apparent from southern Australian heathlands is not an accurate representation of the majority of the community. It is the result of flowering in a few specialised (but often abundant) members of the community (eg. Xanthorrhoea spp., Gill 1981; Nuytsia Lamont \& Downes 2011) plus fire ephemerals, particularly grasses. Flowering intensity in the Lancelin kwongan was greatest in the oldest sites (although not significant), more than 6 years post-fire and occurred earlier than at the one year since fire site. This accords with similar peaks in flowering and fruiting intensity at 8 years post-fire in subtropical heathlands (McFarland 1990). In contrast there is poor correlation with South African fynbos in which a rich suite of geophytes produces an impressive post-fire floral display (Johnson 1992). Geophytes are prominent in both fynbos and Australian heath, but analysis of closely matched sites shows geophytes are more common in the Cape (Cowling and Witkowski 1994) and the hysteranthos 
habit is rare in Kwongan (le Maitre \& Midgley 1992), contributing to the contrast in flowering behaviour between the African and Australian communities. In Brazilian cerrado flowering of grasses after fire is very pronounced (Fontenele $\&$ al. 2020) and this is similar to the frequent abundance of Austrostipa compressa the first year after fire in kwongan (Baker \& al. 2005).

Differences in reproductive activity in the Lancelin heath were due largely to life history characteristics and age structure of individuals, which in turn were related to fire history. Annuals, geophytes, chamaephytes, sub-shrubs, multi-stemmed shrubs and single stemmed shrubs represent the approximate order of time from regeneration to flowering (Griffin pers comm). The earlier and more peaked flowering and fruiting on the most recently burnt site reflected the greater representation of annuals on that site, than on other sites, and the rapid completion of their life cycle before the dry summer in this markedly seasonal environment.

From 2.5 years (site 2) after fire the community phenological pattern in terms of seasonal behaviour showed little change, although number of species flowering decreased (but would eventually plateau) with time since fire. The higher total flowering intensity scores for the older sites, in particular for the pre-1985 site is related to the more protracted flowering of woody perennial species and the greater reproductive effort required to attract pollinators in self-incompatible species (Wills 1989). The fact that flowering intensity was highest in the late winter may be related to greater competition for pollinators at this time of the year when adverse weather conditions limit pollinator foraging.

Peak fruiting activity was more narrowly confined than was flowering, perhaps related to the need by shallow rooted plants to complete fruit set before conditions became excessively dry in summer (Bell \& Stephens 1984). The fact that the longer unburnt sites had higher fruiting intensities in summer than more recently burnt sites is related to the increasingly greater proportion, in biomass terms, of large (deep rooted) woody plants on the long unburnt sites. Lower intensity scores, in general, in comparison with flowering reflects the fact that in many species a low proportion of flowers set fruit (Vaughton 1991).

Fruit production after flowering will be related to the type of fruit/seed produced. Fruit maturation in annuals will be much quicker than in perennials (Segrestin \& al. 2018). Fruiting followed relatively rapidly (one month) after flowering in comparison to fruiting at a site in southern Spain (Herrera 1986) where the main fruiting peak followed flowering by 3 months. Seeds that are destined for the soil seed bank may mature more quickly than those in serotinous infructescences where the woody fruit will take longer to mature than a less substantial fruit. In Spain there was a bimodal peak in fruiting related to nonfleshy (first mature) and fleshy (matured later) fruits. This same trend was apparent in a study of phenology in rainforest in Chile at $40^{\circ} \mathrm{S}$ with a winter maximum rainfall. Shrub species which were mainly zoochorous showed a 3-month separation between peak flowering and fruiting. For tree species which were evenly divided between anemochorous and zoochorous species the peak flowering was later in the season and preceded peak fruiting by only one month (Smith-Ramirez \& Armesto 1994). In Lancelin heaths there are few plants with fleshy fruits and most have small fruits requiring only a short time for development. The fruiting curve is more peaked than the flowering curve with a tail into the autumn indicating longer fruit development in a proportion of the flora, such as those with woody capsules or follicles. Species with myrmecochorous seeds may need to mature in late spring to early summer to coincide with ant activity and such species are common in kwongan vegetation (Lubertazzi \& al. 2010). 
The main trend in fruiting intensity in relation to time since fire was sites longer since fire tended to have higher intensity later in the year than sites burnt more recently. The high fruit numbers, rapid development and fruiting intensity of the recently burnt sites seems to be related to the seeding characteristics of annuals, which, due to phenological cycles, mating systems and post-fire regeneration strategy, tend to produce large quantities of seed (Willson 1983; Wills 1989). The monocarpic fire ephemerals of the kwongan have been found to produce smaller, more numerous seed than the polycarpic ephemerals, which commence reproduction in the second season post-fire (Pate \& al. 1985). In the majority of months the site burnt in 1986 (five years previously) had higher seed production than Site 2 (burnt 2.5 years previously in 1988), but was also generally slightly higher than the site burnt six years previously in 1985 (Site 4). Fruit production of sites burnt in 1985 (site 4) and before 1985 (site 5) were generally similar except in February and October. It seems that fruit production reaches a stable level by at least five years after a fire episode and may even decline in long unburnt heathland (Whelan \& Ayre 2020).

Time to first flowering after fire has been examined for a large number of Western Australian species (Burrows \& al. 2008). While the juvenile period for most forest species was 3 years; seeder species in drier kwongan may be considerably longer (Wooller \& al. 2002). Even if flowering begins 3 years after fire fruit production may take longer, as with sparse flowers from young plants, pollen transfer may be limited, so outcrossing plants in particular may have delayed fruiting. Serotinous species will build up a retained seed bank once flowering is of a sufficient density to attract pollinators. However after a period of production retained seed loses viability or is damaged by predators (e.g. Lamont $\&$ Barker 1988; Whelan \& Ayre 2020) so the seed bank capital will plateau at a certain level, depending on the species involved.

Plant community flowering pattern is clearly most strongly influenced by climatic factors (Herrera 1986; Johnson 1993; Petanidou \& al. 1995; Segrastin \& al. 2018) but fire changes the reproductive phenology spectrum by enabling annuals to enter the community, removing adult tissue of sprouting species and initiating flowering in a minority of species such as monocots (McFarland 1990) which are cued to flower by disturbance. Flowering intensity and number of species flowering shows the same pattern for the early post fire period but after about four years the number of species flowering decreases while peak flowering intensity does not alter from the early spring pattern. From a community point of view there seem to be two components. Firstly, taxa which flower profusely in the first (possibly 2) years after fire, flower early in spring and set seed before summer - most are annuals. These have limited root mass so need to mature fruit and seeds while soil moisture is still available in the upper part of the soil profile. Secondly, there are the core taxa of the heathland, which mostly begin flowering at least 2 years after fire, flower later in spring and continue to fruit into summer. Shrubs with more extensive root run and access to deeper soil moisture can take longer to mature fruit.

\section{Substrate}

Although the edaphic differences between sites were not large, the coastal dune sites contrasted most markedly with the sites on other substrates. They were notable for their more protracted flowering and fruiting activity and the lack of flowering and fruiting synchrony 
in certain species. Similar asynchrony has been observed in dune thicket species of the South African Fynbos (Pierce 1984). In species which fruited asynchronously in fynbos dune thicket, there was variation in the quantity of fruit produced at different times of the year (Pierce 1984). There was a similar trend in fruit production in this study. Lower fruit production in winter may reflect inadequate pollination at this time.

A comparison of reproductive activity at sites on different soils types but with similar fire histories, albeit limited, showed similarities in flowering and fruiting patterns, suggesting that the effect of fire history or fire history combined with other factors influencing reproductive phenology, such as climate may be more important than substrate. A phenological study of three shrubland types in climatically similar sites in South Africa showed that substrate had minimal effect on phenophases (Pierce \& Cowling 1984). Temperature and soil moisture may be more important in determining phenophases than nutrient availability (Heinsohn \& Pammenter 1988; Segrestin \& al. 2018). However, the phenological contrast between the dune and the heathland flora may reflect the cosmopolitan origin of many dune species which is different from the heath species that are part of the autochthonous element of the Australian flora. Johnson (1993) and Linder (2020) have emphasised that there is a relationship between phenological patterns and the phylogeny of species so the prominence of different groups in the different floras might be expected to produce different phenological patterns.

In conclusion, our study emphasises the influence fire on reproductive phenology. From a fire management perspective, the timing and intensity of peak reproductive activity are important aspects to consider in relation to both fire interval and season of fire.

\section{References}

Baker, K. S., Steadman, K. J., Plummer, J. \& Dixon, K. W. 2005: Seed dormancy and germination responses of nine Australian fire ephemerals. - Pl. Soil 277: 345-358.

Beard, J. S. \& Pate, J. S. 1984: Forward. - Pp. xvii-xxii in: Pate, J. S. \& Beard, J. S. (eds), UKwongan - Plant Life of the Sandplain'. - Perth.

Bell, D. T. \& Koch, J. M. 1980: Post-fire succession in the northern jarrah forest of Western Australia. - Australian J. Ecol. 5: 9-14.

— \& Stephens, L. J. 1984: Seasonality and Phenology of Kwongan Species. - Pp. 205-225 in: Pate, J. S. \& Beard, J. S. (eds), Kwongan - Plant Life of the Sandplain. - Perth.

Benson, D. H. 1985: Maturation periods for fire-sensitive shrub species in Hawkesbury sandstone vegetation. - Cunninghamia 1: 339-49.

Bogusch, P., Blazej, L., Tryzna, M. \& Heneberg, P. 2015: Forgotten role of fires in central European forests: critical importance of early post-fire successional stages for bees and wasps (Hymenoptera: Aculeata). - Europ. J. Forest Res.134: 153-166.

Burrows, N. D., Wardell-Johnson, G. \& Ward, B. 2008: Post-fire juvenile period of plants in the south-west Australian forests and implications for fire management. - J. Roy. Soc. Western Australia 91: 163-174.

Carbone, L. M. \& Aguilar, R. 2017: Fire frequency effects on soil and pollinators: what shapes sexual reproduction? - Pl. Ecol. 218: 1283-1297.

Cowling, R. M. \& Witkowski, E. T. F. 1994: Convergence and non-convergence of plant traits in climatically and edaphically matched sites in mediterranean Australia and South Africa. Australian J. Ecol. 19: 220-232. 
Dunn, E. L., Shropshire, F. M., Song, L. C. \& Mooney, H. A. 1976: The water factor and convergent evolution in Mediterranean-type vegetation.- Pp. 492-505 in: Lange, O. L., Kappen, L. \& Schulze, E.-D. (eds), Water and Plant Life. - Heidelberg.

Fontenele, H. G. V., Cruz-Lima, L. F. S., Pacheco-Filho, J. L. \& Miranda, H. S. 2020: Burning grasses, poor seeds: post-fire reproduction of early-flowering Neotropical savanna grasses produces low-quality seeds. - Pl. Ecol. 221: 1265-1274.

Gentilli, J. 1996: Seasonal climates and flowering time. - Western Australian Naturalist 21: 103-118.

Gill, A. M. 1981: Adaptive responses of Australian plant species to fire. - Pp. 234-72 in: Gill, A. M., Groves, R. H. \& Noble, I. R. (eds), Fire and the Australian Biota. - Canberra.

— \& Groves, R. H. 1981: Fire regimes in heathlands and their plant-ecological effects. - Pp. 61-84 in: Specht, R. L. (ed.), Ecosystems of the World: Heathlands and Related Shrublands. Amsterdam.

— \& Ingwerson, I. 1976: Growth of Xanthorrhoea australis R. Br. in relation to fire. - J. Appl. Ecol. 13: $195-203$.

Heinsohn, R. D. \& Pammenter, N. W. 1988: Seasonality of shoot growth and flowering in the fynbos shrub Protea neriifolia cultivated in a summer rainfall area. - South African Journal of Botany 54: 440-444.

Herrera, J. 1986: Flowering and fruiting phenology in the coastal shrublands of Donana, south Spain. - Vegetatio 68: 91-98.

Johnson, S. J. 1992: Plant animal relationships. - Pp. 175-205 in: Cowling, R. M. (ed.), The ecology of fynbos: Nutrients, fire and diversity. - Cape Town.

- 1993: Climatic and phylogenetic determinants of flowering seasonality in the Cape flora. - J. Ecol. 81: 567-575.

Lamont, B. B. \& Barker, M. J. 1988: Seed bank dynamics of a serotinous, fire sensitive Banksia species. - Australian J. Bot. 36: 193-203.

— \& Downes, K. S. 2011: Fire-stimulated flowering among resprouters and geophytes in Australia and South Africa. - Pl. Ecol. 212: 2111- 2125. https://doi.org/10.1007/s11258-011-9987-y

—, He, T. \& Yan, Z. 2019: Evolutionary history of fire-stimulated resprouting, flowering, seed release and germination. - Biol. Rev. 94: 903-928. https://doi.org/10.1111/brv.12483

Lazarina, M., Sgerdelis, S. P., Tscheulin, T., Devalez, J., Mizerakis, V., Kallimanis, A. S., Papakonstantinou, S., Kyriazis, T. \& Petanidou, T. 2017: The effects of fire history in shaping diversity patterns of flower visiting insects in post-fire Mediterranean pine forests. - Biodiv. Conserv. 26: 115-131. https://doi.org/10.1007/s10531-016-1228-1

Le Maitre, C. D. \& Midgely, J. J. 1992: Plant reproductive ecology. - Pp. 135-174 in: Cowling, R. M. (ed.), The ecology of fynbos: Nutrients, fire and diversity'. - Cape Town.

Li, L., Li, Z., Cadotte, M. W., Jia, P., Chen, G., Jin, L. S. \& Du, G. 2016: Phylogenetic conservatism and climatic factors shape flowering phenology in alpine meadows. - Oecologia 182: 419428.

Linder, H. P. 2020: The evolution of flowering phenology: an example from the wind-pollinated Restionaceae. - Ann. Bot. 126: 1141-1153. https://doi.org/10.1093/aob/mcaa129

Lubertazzi, D., Lubertazzi, M. A. A., McCoy, N., Gove, A. D., Majer, J. D. \& Dunn, R. R. 2010: The ecology of a keystone seed disperser, the ant Rhytidoponera violacea. - Journal of Insect Science 10: 158 . doi.org/10.1673/031.010.14118

McFarland, D. C. 1990: Flower and seed phenology of some plants in the subtropical heathlands of Cooloola National Park, Queensland, Australia. - Australian Journal of Botany 38: 501-509.

Milewski, A. V. \& Davidge, C. 1981: The physical environment, floristics and phenology of a Banksia woodland near Perth, Western Australia. - Western Australian Herb. Res. Notes 5: 29-48.

Muir, B. G. 1987: Time between germination and first flowering of some perennial plants. - Kingia 1: $75-83$ 
O’Dowd, D. J. \& Gill, A. M. 1984: Predator satiation and site alteration following fire: Mass reproduction in alpine ash (Eucalyptus delegatensis ) in south-eastern Australia. - Ecology 65: 52-66.

Pate, J. S., Casson, N. E. \& Kuo, J. 1985: Biology of fire ephemerals of the sandplain of the Kwongan of south-western Australia. - Australian J. Pl. Physiol. 12: 654-655.

Petanidou, T., Ellis, W. N., Margaris, N. S. \& Vokou, D. 1995: Constraints on flowering phenology in a phryganic (east Mediterranean shrub) community. - American J. Bot. 82: 607-620. https://doi.org/10.1002/j.1537-2197.1995.tb11505.x

Pierce, S. M. 1984: A synthesis of plant phenology in the fynbos biome. - Pretoria.

— \& Cowling, R. M. 1984: Phenology of fynbos, renosterveld and subtropical thicket in the southeastern cape. - South African J. Bot. 3: 1-16.

Pignatti, E., Pignatti, S. \& Ladd, P. G. 2002: Comparison of ecosystems in the Mediterranean basin and Western Australia. - Pl. Ecol. 163: 177-186. https://doi.org/10.1023/A:1020968010349

Pyke, G. H. 1983: Relationship between time since last fire and flowering in Telopea speciosissima R. Br. and Lambertia formosa Sm. - Australian J. Bot. 31: 293-296.

— 2017: Fire-stimulated flowering: a review and look to the future. - Critical Rev. Pl. Sci. 36: 179189.

Rafferty, N. E. \& Nabity, P. D. 2017: A global test for phylogenetic signal in shifts in flowering time under climate change. - J. Ecol. 105: 627-633. https://doi.org/10.1111/1365-2745.12701

Segrestin, J., Bernard-Verdier, M., Violle, C., Richarte, J., Navas, M.-L. \& Gernier, E. 2018: When is the best time to flower and disperse? A comparative analysis of plant reproductive phenology in the Mediterranean. - Functional Ecol. 32: 1770-1783. https://doi.org/10.1111/1365-2435.13098

Smith-Ramirez, C. \& Armesto, J. J. 1994: Flowering and fruiting patterns in the temperate rainforest of Chiloe, Chile - ecologies and climate constraints. - J. Ecol. 82: 353-365.

Specht, R. L. 1981: Responses to fire in heathlands and related shrublands. - Pp. 395-415 in: Gill, A. M., Groves, R. H. \& Noble, I. R. (eds), Fire and the Australian Biota. - Canberra.

-, Rogers, R. W. \& Hopkins, A. J. M. 1981: Seasonal growth and flowering rhythms: Australian heathlands. - Pp. 5-13 in: Specht, R. L. (ed.), Heathlands and related shrublands. Amsterdam.

—, Moll, E. J., Pressinger, F. \& Sommerville, J. E. M. 1983: Moisture regime and nutrient control of seasonal growth in mediterranean ecosystems. - Pp. 120-132 in: Kruger, F. J., Mitchell, D. T. \& Jarvis, J. U. M. (eds), Mediterranean-Type Ecosystems: The Role of Nutrients'. - Berlin. SPSS Inc. 1986: SPSS Users Guide, 2nd edition. - Chicago.

Turner, B. L., Hayes, P. E. \& Laliberte, E. 2018: A climosequence of chronosequences in southwestern Australia. - European J. Soil Sci. 69: 69-85. https://doi.org/10.1111/ejss.12507

Van der Moezel, P. G., Loneragan, W. A. \& Bell, D. T. 1987: Northern sandplain Kwongan: regeneration following fire, juvenile period and flowering phenology. - J. Roy. Soc. Western Australia 69: 123-132.

Vaughton, G. 1991: Variation between years in pollen and nutrient limitation of fruit-set in Banksia spinulosa. - J. Ecol. 78: 389-400.

Whelan, R. J. \& Ayre, D. J. 2020: Long inter-fire intervals do not guarantee a large seed bank in a serotinous shrub (Banksia spinulosa SM.) - J. Ecol. 108: 1690-1702. https://doi.org/10.1111/1365-2745.13357

Wills, T. R. 1989: Management of the flora utilised by the European honeybee in Kwongan of the northern sandplain of Western Australia. - PhD Thesis, University of Western Australia: Perth.

Willson, M. F. 1983: Plant Reproductive Ecology. - New York.

Wooller, S. J., Wooller, R. D. \& Brown, K. L. 2002: Regeneration by three species of Banksia on the south coast of Western Australia in relation to fire interval. - Australian J. Bot. 50: 311-317. 
Wright, S. J. \& Calderon, O. 1995: Phylogenetic patterns among tropical flowering phenologies - J. Ecol. 83: 937-948.

Addresses of the authors:

Sarah Barrett ${ }^{1}$ \& Philip G. Ladd ${ }^{2 *}$,

${ }^{1}$ Dept. of Biodiversity, Conservation and Attractions, 120 Albany Highway, Albany, 6330 Western Australia.

${ }^{2}$ Environment and Conservation Science, Murdoch University, Murdoch 6150, Western Australia. Email: P.Ladd@murdoch.edu.au

*Corresponding author 